
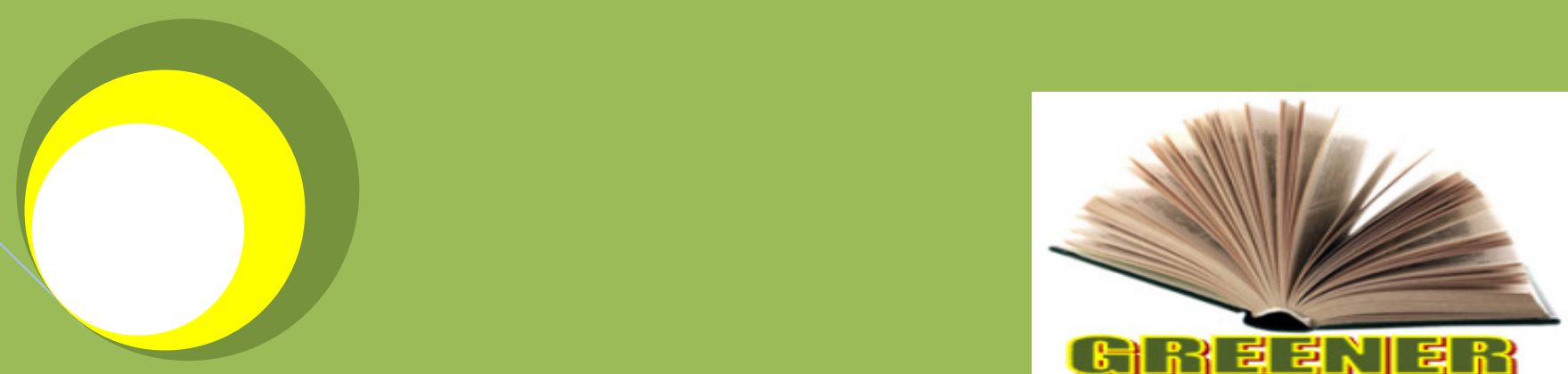

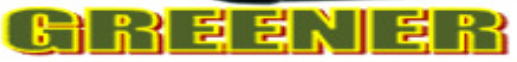
D(0) (U)

Greener. Journal of Biólogical Sciences ISSN: ISSN: 2276-7762 ICV 2012: 5.99

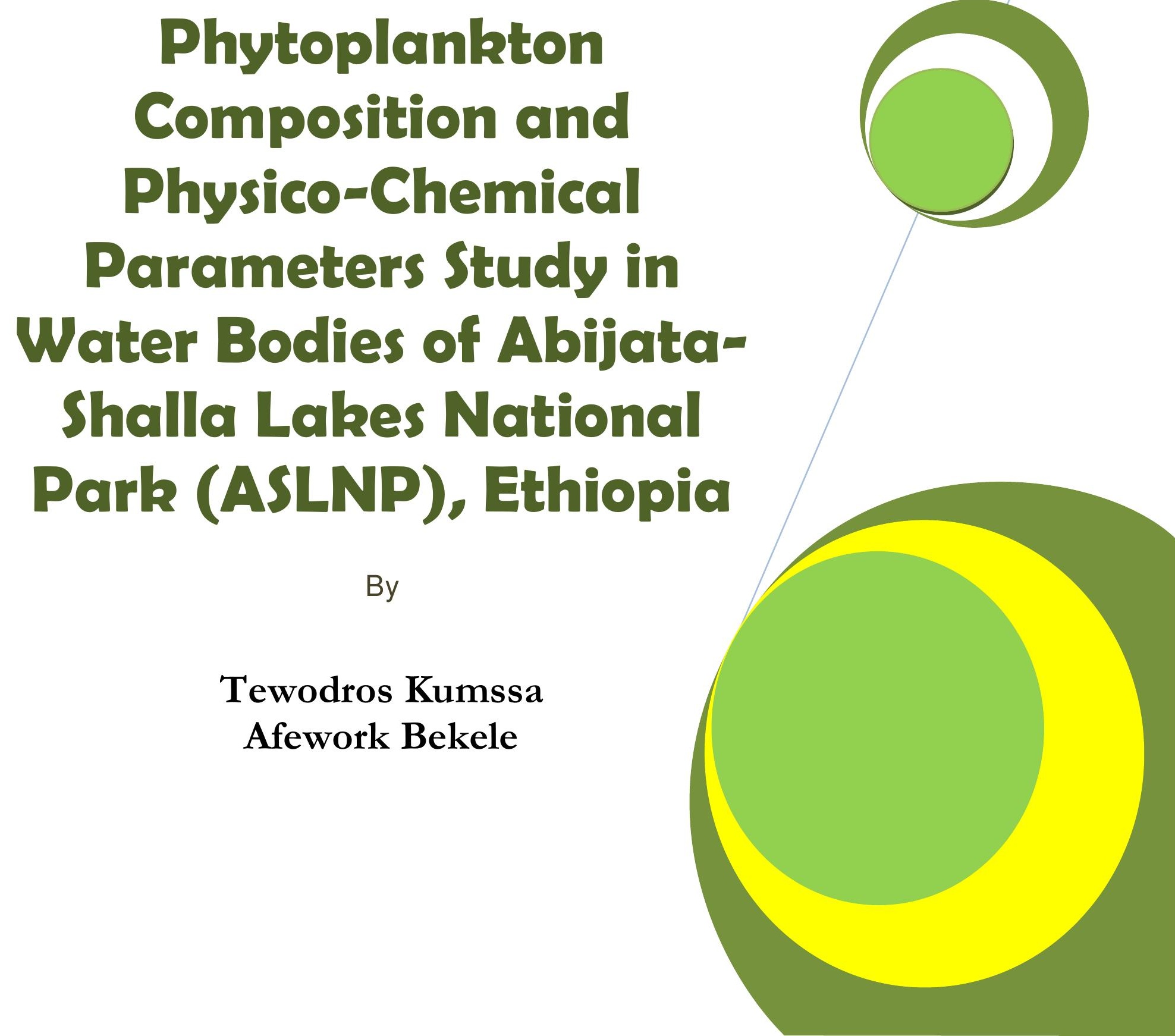




\title{
Phytoplankton Composition and Physico-Chemical Parameters Study in Water Bodies of Abijata-Shalla Lakes National Park (ASLNP), Ethiopia
}

\section{Tewodros Kumssa* and Afework Bekele}

\author{
Department of Zoological Sciences, Addis Ababa University, Addis Ababa, Ethiopia. \\ *Corresponding Author's Email: tewodroskk@gmail.com
}

\begin{abstract}
Abijata-Shalla Lakes National Park is well known in its bird diversity and saline crater lakes. These lakes are most important feeding site of flamingos. However, much of their physico-chemical and its biotic information are not reviewed. The study was carried out from October 2011 to November 2013 during wet and dry seasons to fill the identified gap in physico-chemical characteristics, phytoplankton and level of heavy metals. Physico-chemical characteristics of water were measured using a multiparameter portable instrument (AQUAVIA, Model S× $723 \mathrm{PH} / \mathrm{mV} /$ Cond Meter). For the chemical analysis water samples were collected from the surface water using polyethylene bottles, and were analyzed using standard methods. Phytoplanktons were collected with a phytoplankton net seasonally, counted and identified. A total of $\mathbf{2 3}$ genera were identified from Lake Abijata. Comparatively, a higher number of species was recorded during dry than the wet season. The compositions of phytoplankton were dominated by Arthrospira fusiformis in Lake chitu and Bacillariophyceae in Lake Abijata. In Lake Abijata Bacillariophyceae community was hold $91.21 \%$ of the plankton abundance. Value of $\mathrm{pH}$ and temperature showed insignificant variation, conductivity, salinity and TDS varied widely between lakes and rivers. Water chemistry analysis reflected sodium as the major cation while chloride and bicarbonate were the major anions. The findings of heavy metal indicated that the mean concentration of $\mathrm{Zn}$ was $0.14 \mathrm{mg} / \mathrm{l}$, CU $0.009 \mathrm{mg} / \mathrm{l}, \mathrm{Pb} 0.039 \mathrm{mg} / \mathrm{l}, \mathrm{Fe} 6.17 \mathrm{mg} / \mathrm{l}$ and $\mathrm{Cr} 0.109 \mathrm{mg} / \mathrm{l} /$. Cadmium was not detected in the water samples. The levels of most heavy metals recorded in water were generally low, when compared to the international permissible limits. The analysis of phytoplankton of lakes indicates the water of lakes can be considered different.
\end{abstract}

Keywords: Abijata, Heavy metals, Lakes, Phytoplankton, Physico-chemical, Seasonal.

\section{INTRODUCTION}

The quantitative and qualitative abundance of the phytoplankton were significantly correlated by existing water quality conditions (Partensky et al., 1999). In recent years, much work has been done to explain fluctuations and shifts in the phytoplankton community composition in the soda lakes of the East African Rift Valley and how they influence the abundances of lesser flamingos (Phoeniconaias minor) which inhabit these water bodies (Krienitz et al., 2013). These lakes characterized by having high $\mathrm{pH}$ and conductivity (Oduor and Schagerl, 2007). Arthospira fusiformis, a blue-green algae, is the most abundant phytoplankton in flamingo lakes (Nasirwa, 2000). The abundance of cyanobacteria is responsible for giving the flamingo lakes their characteristic greenish color (Mwatha, 1991). Other groups of phytoplankton common in flamingo lakes are diatoms, which are a large number of unicellular and colonial genera which differ from other algae in the shape of their cells (McCullough et al., 2003). According to UNEP (2002), heavy metals affected flamingos in some Kenya's soda lakes in 2001. The variations in physicochemical and biological compositions depend mainly on the type and nature of the water as well as on the manmade additions or runoff of minerals and chemicals from agriculture soils (Fathi and Flower, 2005) Lake Abijata is known to be productive in phytoplankton. A dominant population of Spirulina species was reported from Lake Abijata in the 1960s (Wood and Talling, 1988). But later it was found to be sub-dominant with frequent blooms of a nitrogen-fixing cyanobacterium Anabaenopsis abijatae (Kebede and Willén, 1998) as the dominant phytoplankton species. The lake currently recognized as a diatoms lake. Lake Chitu still maintains an abundant Spirulina which is the main food source for huge flocks of the lesser flamingo. The three saline lakes in Abijata-Shalla Lakes National Park (ASLNP) are closed and have no or little ground water out flow (Ayenew and Legesse, 2007). The shallower Lake Abijata has Bulbulla and Hora Kelo feeder Rivers. The lake have high sodium, bicarbonate and fluoride ions and the concentration of calcium and magnesium is very low (Ayenew, 2005). A conspicuous feature of these lakes is often 
the presence of over thousands of lesser flamingos (Phoeniconaias minor). The relationship between the physicochemical parameters and phytoplankton production of water bodies are of great importance in management strategies of aquatic ecosystem. Only sparse and irregular data were available on the physico-chemical and biological parameters lakes of ASLNP. The study aims to fill the identified gap in physico-chemical parameters, phytoplankton and level of heavy metals.

\section{MATERIALS AND METHODS}

Study area: Abijata-Shalla Lakes region was established as a National Park by the Ethiopian Wildlife Conservation Organization in 1970 with the aim of conserving the biodiversity of the spectacular number of aquatic birds (Hillman, 1993). ASLNP is one of Ethiopia's National Parks, located in the East Showa Zone comprising three lakes: Abijata, Shalla and Chitu (Fig. 1). Lake Shalla is deepest of the Ethiopian Rift Valley Lakes. It has $266 \mathrm{~m}$ depth. The specific site lies between the coordinates of $7^{\circ} 1545^{\prime}$ and $38^{\circ} 30^{\prime}-38^{\circ} 45^{\prime} \mathrm{E}$; at about $207 \mathrm{~km}$ south from Addis Ababa. It comprises two types of ecosystems namely the water and land together covering a total area of $887 \mathrm{~km}^{2}$ of which $405 \mathrm{~km}^{2}$ is land area while $482 \mathrm{~km}^{2}$ is water body (Senbeta and Tefera, 2001).

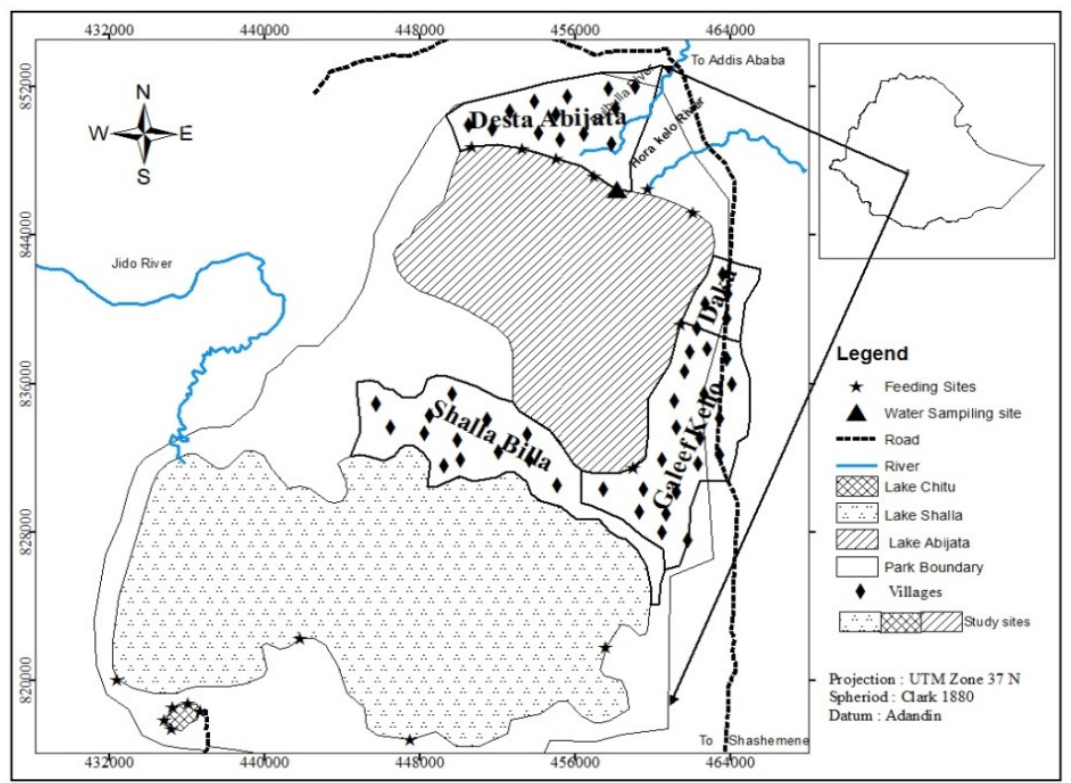

Figure. 1: Map of the study area with study sites.

Sample collection and analysis: Water sampling site was identified as indicated in Fig.1. The phytoplankton samples were collected from October 2011 to November 2013 during dry (November- May) and wet seasons (JuneSeptember) from surface water of Lakes (Abijata and Chitu) using phytoplankton net mesh size $10 \mu \mathrm{m}$. Identification and counting of phytoplankton species were done by use of a binocular light microscope, at a magnification of 150x (oil emersion). Slides for qualitative and quantitative analyses were prepared (in triplicate) and count done using Sedgwick rafter Counting Chamber. Identification of phytoplankton species followed relevant textbook and article (Prescott, 1984;Nwankwo and Onyema, 2003. 40 squares were counted randomly, single cells and filaments were all considered as algae and the results are expressed as algae $\mathrm{ml}^{-1}$ (algae/ ml). The count (algae ml $\mathrm{ml}^{-1}$ of the lake water was calculated according to Wetzel and Likens (2000). The algae counts of major phytoplankton species were added together to give total abundance. Phytoplankton abundance between season in lake Chitu were showed in a more modified form, the algal/cells are classified as 'very common', 'common', 'rare', etc., based on rough counts and judgments by the eye. To determine the physico-chemical characteristics of water we measured different variables. Water temperature, $\mathrm{pH}$ and conductivity, total dissolved solid (TDS) and salinity were measured in situ upon sampling using a multiparameter portable instrument (AQUAVIA, Model Sx $723 \mathrm{PH} / \mathrm{mV} /$ Cond Meter). Color was measured using visual comparison method, about $20 \mathrm{ml}$ of the sample and $20 \mathrm{ml}$ of distilled water were taken in two separate wide mouthed test tubes. The results were tabulated (as clear, greenish, grayish, brownish, blackish, etc) by comparing the color of the sample with distilled water as adopted by APHA (1998). For the chemical analysis 2 liters of water samples were collected from the surface water $(1-2 \mathrm{~cm})$ using acid pre - washed polyethylene 
bottles. Each sample was extracted by placing the plastic collection bottle directly in the water source, rinsing three times, and then filling completely. Nutrients measured include major cations, anions and some trace metals. Analysis of the lake water was done as per the standard method of American Public Health Association (APHA, 1998). For trace metal and cation analysis water samples acidified with few drops of concentrated nitric acid (HNO3) to bring the $\mathrm{pH}$ of the samples below 2 in the field, immediately after collection and all contained in an icebox with ice to preserve the samples in cool condition and analysis of nutrient done in laboratory. ANOVA and Chi-Square test were performed to find out statistically significant difference among various variables using stata version 12 software.

\section{RESULTS}

Two major phytoplankton classes namely, Bacillariophyceae (Diatoms) and Cyanophyceae (blue green algae) were identified from Lake Abijata. These classes were further identified into 23 genera (Table 1).

Table 1: List of phytoplankton identified and their seasonal occurrence in Lake Abijata

\begin{tabular}{|c|c|c|}
\hline $\begin{array}{l}\text { Phytoplankton species } \\
\text { (Lake Abijata }\end{array}$ & Frequency & Seasonality \\
\hline \multicolumn{3}{|l|}{ Cyanophyceae } \\
\hline$\overline{\text { Oscillatoria sp. }}$ & Very common & Both seasons \\
\hline Chroococcus spp. & Common & Both seasons \\
\hline Aphanizomennon sp. & Rare & Dry season \\
\hline Synechococcus sp. & Common & Both seasons \\
\hline $\begin{array}{l}\text { Merismopedia sp. } \\
\text { Bacillariophyta }\end{array}$ & Rare & Wet season \\
\hline$\overline{\text { Cymbella spp. }}$ & Common & Both seasons \\
\hline Nitzschia spp. & Rare & Dry season \\
\hline Melosira spp. & Very common & Both seasons \\
\hline Pinnlaria spp. & Very rare & Dry season \\
\hline Fragillaria sp. & Very rare & Dry season \\
\hline Synedra sp. & Very rare & Dry season \\
\hline Achnanthes sp. & Very rare & Dry season \\
\hline Navicula spp. & Very common & Both seasons \\
\hline Diploneis sp. & Very rare & Dry season \\
\hline Rhopalodia spp. & Very common & Both seasons \\
\hline Mastogloia sp. & Common & Both seasons \\
\hline Cyclotella spp. & Very common & Both seasons \\
\hline Rhoicosphenia sp. & Common & Dry season \\
\hline Actinastrum sp. & Very rare & Dry season \\
\hline Thalassiosira sp. & Common & Dry season \\
\hline Amphora spp. & Very rare & Both seasons \\
\hline Stauroneis sp. & Rare & Dry season \\
\hline Anomoeoneis sp. & Rare & Dry season \\
\hline
\end{tabular}

Diatoms contributed in greater proportion in terms of frequency of occurrence than Cyanophyceae. Diatoms were represented by 18 genera and blue green algae by 5 genera. The most very common diatoms throughout the study period were represented by Navicula spp., Cyclotella spp., Rhopalodia spp. and Melosira spp. Cyanophyceae were very commonly represented by Oscillatoria sp. Out of the 23 phytoplankton sampled, 12 species were restricted to the dry season, only one, Merismopedia sp. was recorded during the wet season while 10 species occurred during both seasons. Bacillariophyceae (diatoms) were represented by 18 genera but only two genera (Navicula spp. and Cyclotella spp.) produced highest numerical concentrations. Bacillariophyceae contributed $91.21 \%$ of the total taxa followed by Cyanophyceae (8.79\%). Diatoms varied from 7227 to $82387 \mathrm{algal} / \mathrm{ml}$ while blue green algae varied from 1132 to $7500 \mathrm{algal} / \mathrm{ml}$ (Table 2). Peaks of abundance of diatoms occurred during dry season and Cyanophyceae during the wet season. The density of all genera, varied significantly between seasons. Population of Navicula spp. $\left(x^{2}=25.55, d f=1 p<0.05\right)$, Cyclotella spp. $\left(x^{2}=18.54, d f=1 p<0.05\right)$, Melosira spp. $\left(x^{2}=24.39, d f=1 P<0.05\right)$, Rhopalodia spp. $\left(\mathrm{x}^{2}=6.59, \mathrm{df}=1 \mathrm{P}<0.05\right)$ and Oscillatoria spp. $\left(\mathrm{x}^{2}=8.82, \mathrm{df}=1, \mathrm{P}<0.05\right)$. 
Table 2: Seasonal variation in abundance of very common phytoplankton species in Lake Abijata from 2011 to 2013

\begin{tabular}{lcc}
\hline Species & Wet season (algal $/ \mathrm{ml})$ & Dry season $($ algal $/ \mathrm{ml})$ \\
Bacllariophyceae & & \\
Navicula spp. & 4600 & 65000 \\
Cyclotella spp. & 539 & 12500 \\
Melosira spp. & 840 & 4250 \\
Rhopalodia spp. & 1248 & 637 \\
Total (\%) & $7227(8.06 \%)$ & $82387(91.94 \%)$ \\
& & \\
Cyanophyceae & & 1132 \\
Oscillatoria spp. & 7500 & $1132(13.11 \%)$ \\
Total (\%) & $7500(86.89 \%)$ & $83519 \pm 11.4$ \\
Grand total & $14727 \pm 8.1$ &
\end{tabular}

Phytoplankton population from Lake Chitu was observed to be distinctly different (Table 3). Abijata was basically a diatom lake while Lake Chitu was mono lake dominated by Arthrospira fusiformis, with less frequent species of diatoms.

Table 3: Seasonal abundance and list of phytoplankton identified from Lake Chitu

\begin{tabular}{lcccc}
\hline Species & Diatoms & Cyanophytes & Dry season & Wet season \\
\hline Arthrospira fusiformis & & $* * * * * *$ & Very common & Very common \\
Epithemia zebra & $* * *$ & & Very rare & Very rare \\
Navicula halophila & $* * * *$ & & Very rare & Very rare \\
Cyclotella Spp. & $* * * *$ & & Very rare & Very rare \\
Rhopalodia Spp. & $* * * *$ & & Very rare & Very rare \\
\hline
\end{tabular}

The physico-chemical characteristics of lakes and associated rivers of Lake Abijata are shown in Table 4 . The values of $\mathrm{pH}$ were not significantly different $\left(\mathrm{x}^{2}=0.19, \mathrm{df}=1 \mathrm{p}>0.05\right)$ between dry and wet seasons in all lakes and rivers. Similarly there was no significant difference in temperature between lakes $\left(x^{2}=1.21, d f=2 p>0.05\right)$. While significant variation was obtained in conductivity $\left(x^{2}=20.69, d f=2 p<0.05\right)$, salinity $\left(x^{2}=5.21, d f=2 p<0.05\right)$ and TDS $\left(x^{2}=23.73, d f=2 p<0.05\right)$ between the different lakes. Lakes also had a varied color ranging from dark to green.

Table 4: Mean value of physical and chemical features in different water bodies during wet and dry seasons

\begin{tabular}{|c|c|c|c|c|c|c|c|c|c|c|}
\hline \multirow[t]{4}{*}{ Lakes/ rivers } & \multicolumn{10}{|c|}{ Physico-chemical parameters during dry and wet season } \\
\hline & \multirow{2}{*}{\multicolumn{2}{|c|}{$\mathrm{pH}$}} & \multirow{2}{*}{\multicolumn{2}{|c|}{$\begin{array}{l}\text { Conductivity } \\
(\mathrm{mS} / \mathrm{cm})\end{array}$}} & \multirow{2}{*}{\multicolumn{2}{|c|}{$\begin{array}{l}\text { Salinity } \\
(\mathrm{mg} / \mathrm{l})\end{array}$}} & \multirow{2}{*}{\multicolumn{2}{|c|}{$\begin{array}{l}\text { TDS } \\
(\mathrm{mg} / \mathrm{l})\end{array}$}} & \multirow{2}{*}{\multicolumn{2}{|c|}{$\begin{array}{l}\text { Temperature } \text { Color } \\
\left({ }^{0}{ }_{c}\right) \\
(\text { visible })\end{array}$}} \\
\hline & & & & & & & & & & \\
\hline & Dry & Wet & Dry & Wet & Dry & Wet & Dry & Wet & Dry & Wet \\
\hline Abijata & 9.5 & 9.2 & 30.9 & 14.1 & 21500 & 9730 & 38500 & 14100 & 26 & light green \\
\hline Shalla & 9.7 & 9.5 & 24.3 & 21.1 & 18400 & 13700 & 24600 & 22300 & 27 & dark \\
\hline $\begin{array}{l}\text { Chitu } \\
\text { Hora kelo }\end{array}$ & 10.3 & 10 & 62.2 & 58.1 & 42000 & 37000 & 83300 & 78000 & 24 & green \\
\hline $\begin{array}{l}\text { River } \\
\text { Bulbulla }\end{array}$ & 9.2 & 9 & 2.79 & 1.8 & 5780 & 1250 & 9200 & 1780 & 21 & 16.4 \\
\hline River & 8.1 & 7.9 & 0.482 & 0.467 & 260 & 210 & 360 & 298 & 22 & 18 \\
\hline
\end{tabular}

The current study and compilation of the sparse chemical data available since 1926 have showed that regular measurements of nutrient levels have not been carried on the lake (Tables 5). These parameters are considered to be fundamental for evaluating water quality. 
Table 5:- Irregular record of the physico-chemical characteristics of Lake Abijata (mg/l)

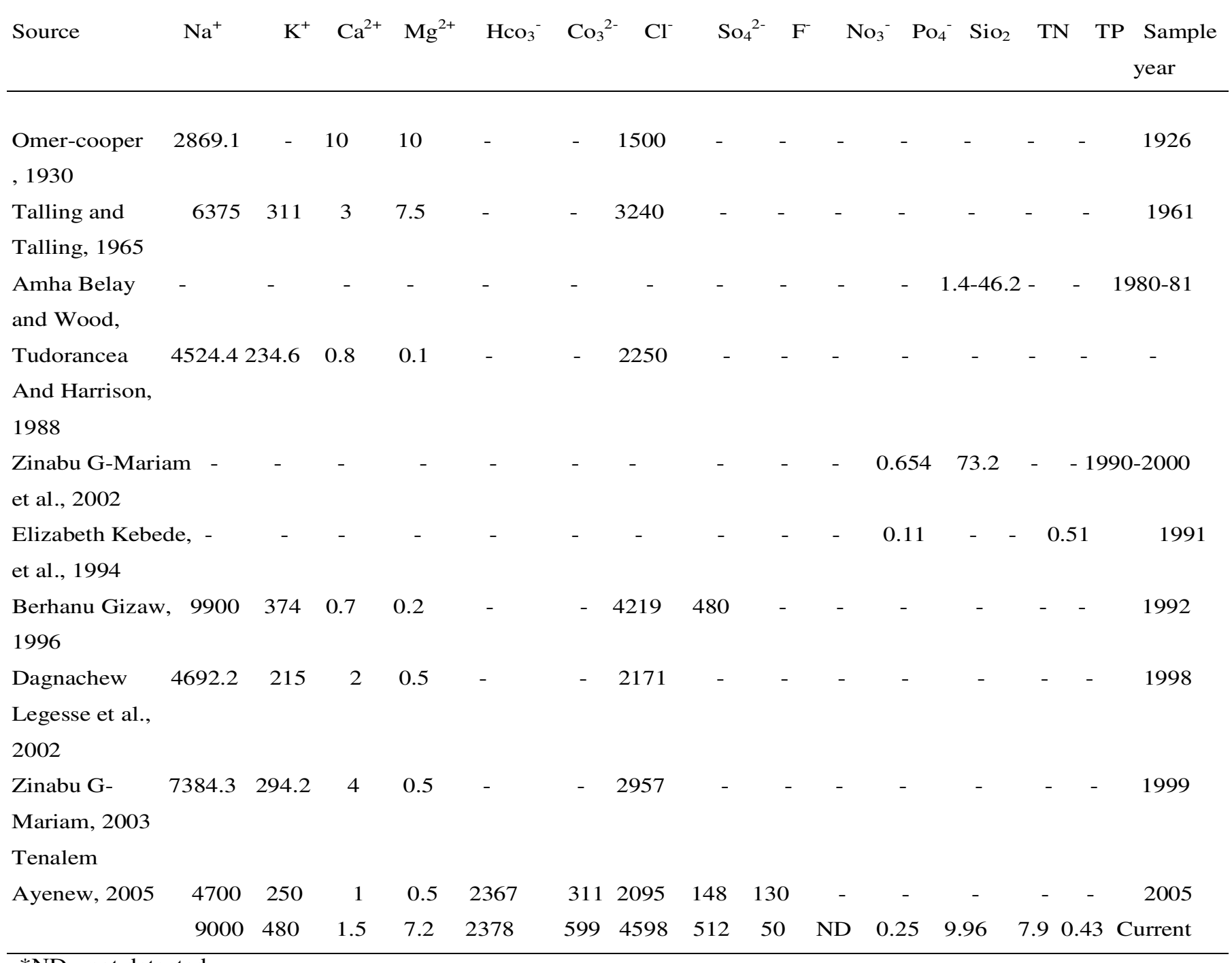

$* \mathrm{ND}=$ not detected

Five metals were detected in the water samples of Lake Abijata at varying concentrations. These were Iron (Fe), Lead $(\mathrm{Pb})$, Zinc $(\mathrm{Zn})$, Chromium $(\mathrm{Cr})$ and Copper $\mathrm{Cu}$ ). Cadmium $(\mathrm{Cd})$ was practically not detected at the sampling site in the lake. The concentration of $\mathrm{Fe}$ in the water column was $6.17 \mathrm{mg} / \mathrm{l}, \mathrm{Cr} ; 0.109 \mathrm{mg} / \mathrm{l}, \mathrm{Pb} ; 0.039 \mathrm{mg} / \mathrm{l}$ and $\mathrm{Cu}$; $0.009 \mathrm{mg} / \mathrm{l}$ (Table 6).

Table 6: Concentrations of heavy metals in Lake Abijata with standard limits (Source: US EPA, 2008) in mg/l

\begin{tabular}{lll}
\hline Parameters & Observed value & Standards (US EPA) \\
\hline $\mathrm{Fe}$ & 6.17 & 0.3 \\
$\mathrm{Cr}$ & 0.109 & 0.1 \\
$\mathrm{~Pb}$ & 0.039 & 0.015 \\
$\mathrm{Cu}$ & 0.009 & 1.3 \\
$\mathrm{Cd}$ & $\mathrm{ND}$ & 0.005 \\
$\mathrm{Zn}$ & 0.14 & 5
\end{tabular}

$\mathrm{ND}=$ not detected 
Most heavy metals present in the lake water do not pose any problem as the concentrations were well within US Environmental Protection Agency standard limits except iron and lead.

\section{DISCUSSION}

Some genera from both classes were observed in both wet and dry seasons as a tolerant species. The possible reason for this observation might be its resilient ability to withstand the varied environmental factors. Seasonal differentiation of most species sampled revealed higher values during dry than wet season. The difference was mainly due to the difference in physical and chemical factors. Therefore, the influence of season is important in the management of water quality and phytoplankton. According to Kufel (2001) the seasonal appearance of phytoplankton differs significantly, with physical factors (temperature, water mixing underwater, light, climate), chemical (nutrient level) and biotic factors (grazing and parasitism). Bacillariophyta was the first most diverse group of algae comprising $91.21 \%$ of the total phytoplankton diversity of a lake. All diatoms except Cocconeis spp. in the studied lake underwent marked seasonal changes in relative abundance over the study period. The genus represented by the most abundant species is Navicula. The level of motile diatoms like (Navicula) has been used as an index of siltation and is able to migrate to the surface if covered by silt and their level becomes high with increasing siltation in lakes (Kutka and Richards, 1996). The overabundance of this genus in Lake Abijata may be related to this fact.

There were marked variations in phytoplankton population between lakes, apparently due to the difference in water quality. It is well known that, the changes in physico-chemical characteristics of any water mass lead to concomitant qualitative and quantitative changes in phytoplanktonic organisms (Fathi and Flower, 2005). The pH of all lakes and rivers exhibits some seasonal insignificant variability with values highest in the dry than wet season. It also did not show significant changes compared to previously records. According to Zinabu Gebremariam (2002), it was not expected to see significant changes in $\mathrm{pH}$ of these well buffered lakes, especially in a continent where acid rain is not a problem. The significant seasonal variation on conductivity, salinity and TDS value between lakes might be related with the large seasonal difference of water level of lakes, retention time and freshwater supply through river flowing into the lakes. This is attributed to the dry period, as water level is continuously decreasing due to evaporation it leaves the ions behinds, which result in higher readings. Normally, the presence of high water and rainfall tends to dilute the ions thus giving lower values during wet season. According to Trivedy et al. (1989) also the variation in such values seasonally is mostly due to increased in the concentration of ions, because of evaporation; the dilution resulted from precipitation brings down its values. Color of water was light green for Lake Abijata, dark for Lake Shalla and green for Lake Chitu. The difference might be mainly due to the difference in metallic ions, suspended matter and phytoplankton type among lakes. The results obtained from the analysis of water chemistry of Lake Abijata demonstrate the remarkable ionic homogeneity of the lake, with $\mathrm{Na}^{+}$and $\mathrm{Cl}^{-}$always dominant. Chemical analysis made by the authors revealed a considerable fluctuation in the ionic concentration of the lake. On the present study the dominant cation, sodium and potassium showed a marked increase. In pertinent other studies, Njenga (2004) elaborated that unlike most lakes where the major cations are the divalent cations, particularly $\mathrm{Ca}^{2+}$ and $\mathrm{Mg}^{2+}$, the Rift Valley lakes have the monovalent cation $\mathrm{Na}^{+}$as the major cation. Predominance of $(\mathrm{Na}+\mathrm{K})$ over $(\mathrm{Ca}+\mathrm{Mg})$ and the low contribution of calcium and magnesium in the cationic composition, were attributed to high $\mathrm{pH}$ related precipitation of calcite $(\mathrm{CaCO} 3)$ and dolomite $(\mathrm{CaMg}(\mathrm{CO} 3) 2)$, especially in lakes Nakuru and Elementaita. Compared to the last record of Ayenew (2005), the present study has shown more than double increase in chloride. The extent increase might be in relation to fast decline of the lake water level or due to the difference on the inflow and outflow conditions and evaporative concentration. Silica $\left(\mathrm{SiO}_{2}\right)$ is an important element for diatom growth. Diatoms were currently most abundant in Abijata Lake. The current Silica content was $9.96 \mathrm{mg} / \mathrm{l}$. The decline from former level of $(73.2 \mathrm{mg} / \mathrm{l})$ may indicate a close linkage between silicon and diatom growth. Periodic Si depletion related to the abundance of diatoms was earlier reported by Belay and Wood (1982). The result showed most heavy metals levels were within the limits set for drinking water, whereas Fe is by far higher than the allowable limit of (US EPA, 1979). The level of $\mathrm{Pb}$ was also beyond the permissible limits. There was no data available to provide evidence of an anthropogenic source for such detected heavy metals, the natural transportation mechanism for the movement of iron into the lake from weathering of minerals may be a cause for such value. The presence of $\mathrm{Pb}$ in the samples can be explained by vehicles washed in Bulbulla River deposits of combustion particles and oil, taken by rivers to the lake. 


\section{CONCLUSION}

Analysis and interpretation of the data on phytoplankton and water quality parameters provided the necessary information to assess the impact of human related activities on the hydrobiology of the lakes. The population of the different species was greatly affected by the physico-chemical properties of the lakes. The presence of high Navicula has been used as index of siltation. Accumulation of such metals may be a threat to the survival of organisms (fauna and flora) in the future.

\section{ACKNOWLEDGEMENT}

First author wish to thank Addis Ababa University for providing required facilities for carrying out the above research work.

\section{REFERENCE}

APHA (American Public Health Association) (1998). Standard Methods for the examination of water and wastewater. $19^{\text {th }}$ ed., American Public Health Association, Washington, D.C.

Ayenew T (2005). Major ions composition of the groundwater and surface water systems and their geological and geochemical controls in the Ethiopia volcanic terrain. SINET: Ethiop. J. Sci. 28:171-188.

Ayenew T and Legesse D (2007). The changing face of the Ethiopian Rift lakes: call of the time. Lakes and reservoirs research and management. 12:149-165.

Belay A and Wood RB (1982). Limnological aspects of algal bloom on Lake Chamo (Gamu Goffa Administrative region), Ethiopia. SINET: Ethiop. J. Sci. 5: 1-19.

Fathi AA and Flower RJ (2005). Water quality and phytoplankton communities in Lake Qarun (Egypt). Aquat. Sci. 67: 350-362.

Hillman JC (1993). Ethiopia: Compendium of Wildlife Conservation Information. Vol. 1 and 2. NYZS. The Wildlife Conservation Society International, New York and Ethiopian Wildlife onservation Organization, Addis Ababa.

Kebede E and Willén E (1998). Phytoplankton in a salinity-alkalinity series of lakes in the Ethiopian Rift Valley. Algolog. studies 89: 63-96.

Krienitz L, Dadheech PK and Kotut K (2013). Mass developments of a small sized ecotype of Arthrospira fusiformis in lake Oloidien, Kenya, a new feeding ground for lesser flamingos in East Africa. Fottea, Olomouc 13: 215-225.

Kufel L (2001). Uncopling of chlorophyll and nutrients in lakes, possible reasons, expected Consequences. Hydrobiologia 443:59-67.

Kutka, F.J. and Richard, C. (1996). Relating diatoms assemblage structure to stream habitat quality. J. North Am. Benthol. Soc. 15: 469-480.

McCullough GP, Aebischer A and Irvine K (2003). Satellite tracking of flamingos in southern Africa: the importance of small wetlands for management and conservation. Oryx 37: 480-483.

Mwatha WE (1991). Microbial Ecology of Kenyan Soda Lakes. Ph.D. Thesis, University of Leicester, UK.

Nasirwa O (2000). Conservation Status of flamingos in Kenya. Waterbirds 23: 47-51.

Njenga JW (2004). Comparative studies of water chemistry of four tropical lakes in Kenya and India. Asian J. Wat. Environ. Pollu. 1:87-97.

Nwankwo E and Onyema IC (2003). A checklist of Planktonic Algae off Lagos Coast. J. Sci. Res. Develop. 9: 75-85.

Oduor SO and Schagerl M (2007). Phytoplankton primary productivity characteristics in response to photosynthetically active radiation in three Kenyan Rift Valley alkalinesaline lakes. Journal of Plankton Research 29: 1041-1050.

Partensky F, Blanchot $\mathrm{J}$ and Vaulot D (1999). Differential distribution and ecology of Prochlorococcus and Synechococcus in oceanic waters: A Review. Bulletin Institute of Oceanography, Monaco 19: 457-475.

Prescott GW (1984). How to know the freshwater algae $3^{\text {rd }}$ ed. WMC Brown Comp. Pub. Dubuque. Lowa.

Senbeta F and Tefera F (2001). Environment crisis in the Abijiata-Shalla Lakes national park. Walia 22:1-13.

Trivedy RK, Goel PK, Shrotri AC, Ghadge MR and Khatavkar SD (1989). Quality of lentic water, water resources in south western Maharastra, India. In: Perspectives in Aquatic Biology, PP: 215-235, (Khulke, R.D.,ed). Papyrus Pub. House, New Delhi.

UNEP (2002). African Environment Outlook: past, present and future. Available at: (http: //www.unep.org/dewa/Africa/publication/AEO-1/index.htm).

US EPA (1979). Methods for chemical analysis of water and wastes. Cincinnati: EPA-600/4-79-020.

Wetzel RG and Likens GE (2000) Limnological analyses. 3rd ed. Verlag, New York, Inc. N.Y. 
Wood RB and Talling JF (1988). Chemical and Algal relationship in a salinity series of Ethiopian inland waters. Hydrobiologia 158:29-67.

Zinabu Gebremariam (2002). The Ethiopian rift valley lakes: major threats and strategies for conservation. In: Ethiopian Rift valley Lakes, PP. 259-271 (Tudorancea, C. and Taylor, W.D., eds). Backhuys publishers, Leiden, The Netherlands. 